\title{
Salvaging a solitary necrotic testis in a quadriparetic
}

\author{
Ranjit Chaudhary, ${ }^{1}$ Kulwant Singh, ${ }^{2}$ Ankit Jain, ${ }^{2}$ Rakesh Biswas ${ }^{3}$
}

${ }^{1}$ Unit of Urology, Department of Surgery, People's College of Medical Sciences, Bhopal, Madhya Pradesh, India

${ }^{2}$ Department of Surgery, People's College of Medical Sciences, Bhopal, Madhya Pradesh, India

${ }^{3}$ Department of Medicine, People's College of Medical Sciences, Bhopal, Madhya Pradesh, India

\section{Correspondence to} Professor Rakesh Biswas, rakesh7biswas@gmail.com

Accepted 21 October 2014

\section{DESCRIPTION}

A 40-year-old man with quadriparesis presented in January 2014 with pain and swelling in the left testis for 2 weeks. He had sustained cervical spine injury 2 years earlier and had an indwelling urethral catheter since then. He had undergone a right orchiectomy 1 year prior for severe infection.

On examination, a clinical diagnosis of acute epididymo-orchitis was made, which was confirmed on ultrasonogram. Routine blood investigations revealed anaemia with leucocytosis and elevated erythrocyte sedimentation rate. Urinalysis showed pyuria and culture was positive for Escherichia coli.

The patient was hospitalised, intravenous antibiotics were started along with supportive treatment. The urethral catheter was substituted by a supra pubic catheter.

Despite these measures, the testicular inflammation did not subside. After 3 weeks pus started discharging from the anterior surface of the scrotum. Ultrasonogram revealed a large abscess in the anterior part of the testis (figure 1).

Surgical intervention was planned. The anterior aspect of the testis was found to be necrotic with foul smelling pus discharge (figure 2). Nearly half of the testicular volume was necrotic and debrided (figures 3 and 4). The healthy edges were not approximated and the wound was left open. The pus was colonised by E. coli. After 5 days the wound was found to be healthy (figure 5) and was closed in layers. Subsequent recovery was uneventful. Histopathology revealed chronic inflammation (figure 6). Ultrasonogram and scrotal Doppler performed after 1 month showed a testicular volume of $8 \mathrm{~mL}$ with normal vascularity. The free testosterone was $15.8 \mathrm{pg} / \mathrm{mL}$ (reference range 8.69-54.69 pg/mL).

\section{DISCUSSION}

Epididymo-orchitis $^{1}$ is common in men aged 15-30 and in men aged over 60. E. coli causing urine infections can sometimes travel down the vas

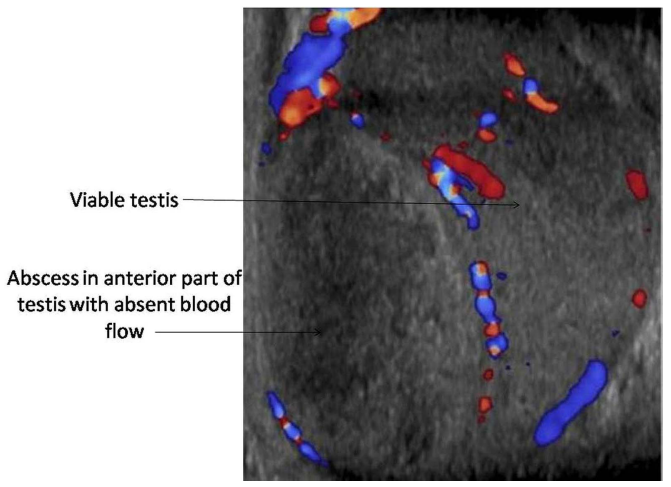

Figure 1 Ultrasonogram image depicting abscess in the anterior aspect of the testis with absent blood flow. deferens. This can happen at any age and is the most common cause of epididymo-orchitis in men aged over 35 as partial blockage of urine flow becomes more common with increasing age secondary to prostatic enlargement or narrowing of the urethra.

The most common cause of epididymo-orchitis in young sexually active men remains chlamydial and gonorrhoeal infections. These infections typically involve the urethra and spread to the epididymis and testis in a retrograde fashion. Urethral instrumentation, injury to the scrotum and surgeries on the prostate can also lead to this condition. Mumps epididymo-orchitis is now only rarely seen due to widespread vaccinations.

Infections from other parts of the body such as tuberculosis and brucellosis can, though rarely, infect the testes by haematogeneous spread in patients with compromised immunity. Schistosomiasis can also cause epididymo-orchitis. Non-infective epididymoorchitis may be seen in Behçet's disease or due to intake of amiodarone at a daily dose of $>200 \mathrm{mg}$.

Epididymo-orchitis and acute testicular torsion have a similar clinical presentation. Moreover, both conditions have similar ultrasonogram findings of enlarged hypoechoic epididymis and testis. However, on colour Doppler the vascularity is increased in epididymo-orchitis and decreased in testicular torsion. Advanced epididymo-orchitis may cause testicular infarction as a result of extrinsic compression of testicular vascular supply by enlarged epididymis and spermatic cord and pyocele. It may also cause testicular and scrotal abscess, seen as a complex echoic mass on ultrasonogram. The latter two presentations mandate surgical intervention.

The patient in our case was a quadriparetic. The ideal care for such patients is 'clean intermittent self catheterisation'. However, due to lack of adequate nursing care our patient had an

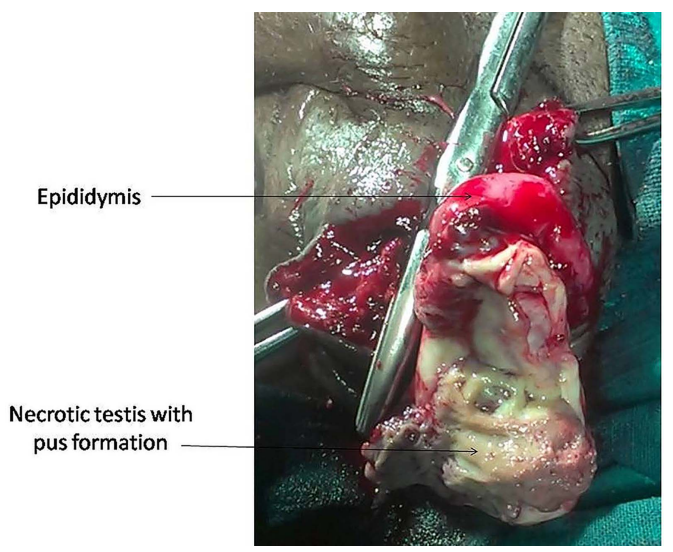

Figure 2 Necrosis in the anterior aspect of the right testis. 


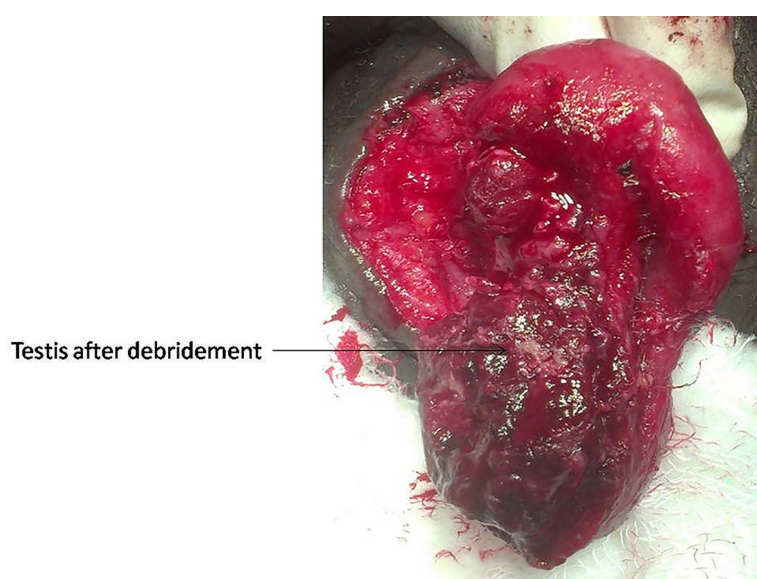

Figure 3 Anterior aspect of the testis after debridement.

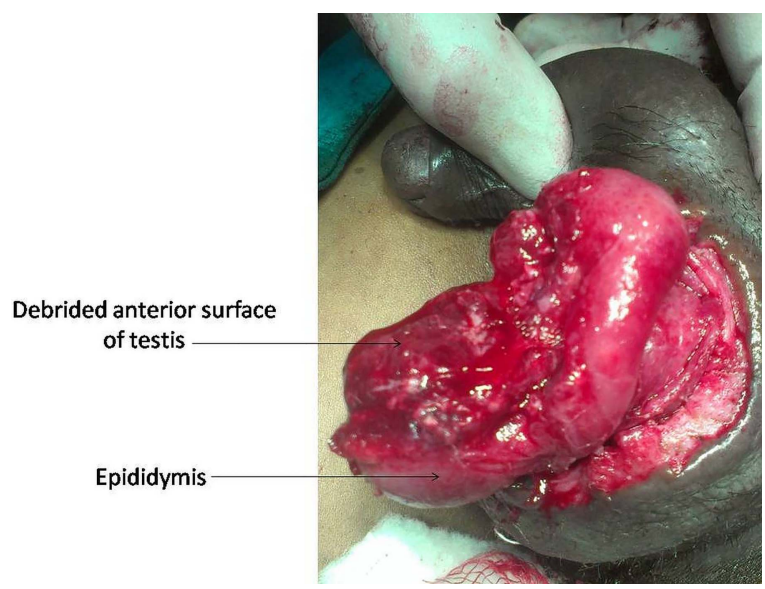

Figure 4 Lateral aspect of the testis after debridement.

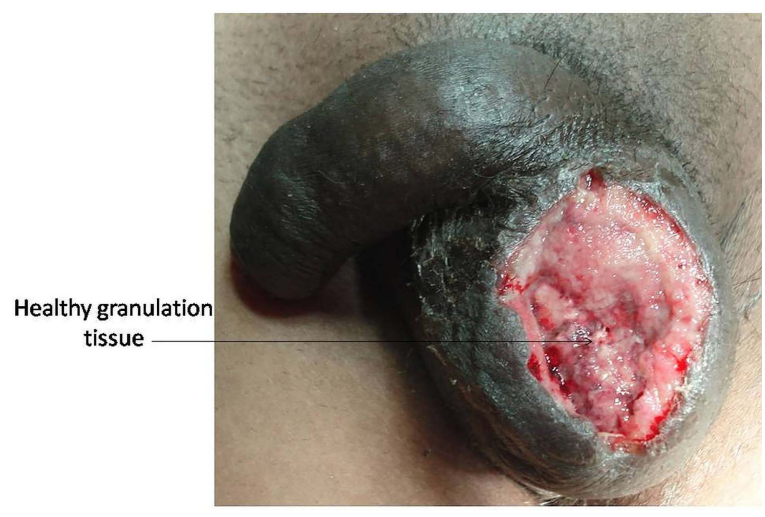

Figure 5 Healthy granulation tissue seen after 5 days.

indwelling urethral catheter for 2 years. A long-standing urethral catheter may have led to urethritis that resulted in epididymo-orchitis. This further led to testicular necrosis and scrotal abscess in this patient.

In a case of epididymo-orchitis with an indwelling urethral catheter, the catheter must be removed or replaced with a supra pubic catheter. This patient had undergone an orchiectomy on the right side perhaps for a similar presentation.

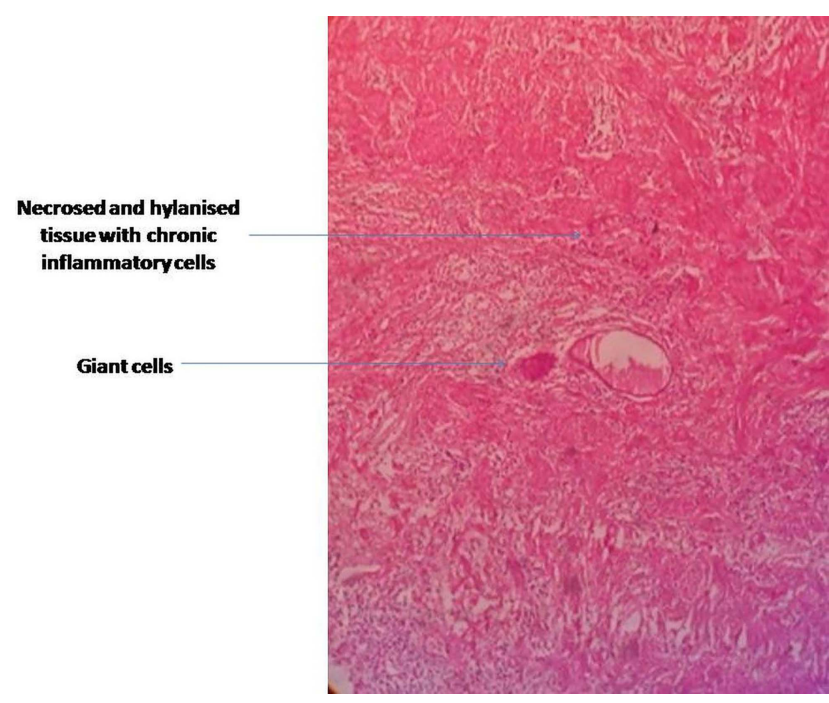

Figure 6 Histopathology confirming chronic inflammation.

It is important to note that two procedures not only prolonged the hospital stay but also increased the cost of the treatment. Had the contralateral testis been normal, it would have been more prudent to perform an orchiectomy. This being a case of a solitary testis, we wanted to conserve as much testicular tissue as possible to ensure that a severe depletion of endogeneous testosterone production would not take place. Tunical edges were not approximated at the time of debridement as we wanted to be certain that further extension of infection had not taken place.

Despite an abscess, the left solitary testis was successfully salvaged. Although there are several case reports where orchiectomy has been performed for testicular abscess, it is rare to salvage a testis in this situation. ${ }^{2} 3$

\section{Learning points}

- Long-term indwelling urethral catheters should be avoided.

- Even in cases of testicular abscess and necrosis it may be possible to salvage the testis.

- While performing debridement for testicular abscess, a staged closure may be performed to confirm the viability and to ensure that further necrosis has not taken place.

Contributors RC, KS and AJ performed the surgery on the patient. RB assisted in preparing the manuscript.

Competing interests None.

Patient consent Obtained.

Provenance and peer review Not commissioned; externally peer reviewed.

\section{REFERENCES}

1 Nickel JC. Prostatitis and related conditions, orchitis and epididymitis. In: Wein AJ, Kavoussi LR, Novick AC, Partin AW, Peters CA. eds. Campbell-Walsh urology. 10th edn. Philadelphia: Saunders-Elsevier, 2012:353-6.

2 Muttarak M, Chiangmai WN, Kitirattrakarn P. Necrotising epididymo-orchitis with scrotal abscess. Biomed Imaging Interv I 2005;1:e11.

3 Kashiwagi B, Okugi $\mathrm{H}$, Morita T, et al. Acute epididymo-orchitis with abscess formation due to Pseudomonas aeruginosa: report of 3 cases. Hinoyokika Kiyo 2000;46:915-18. 
Copyright 2014 BMJ Publishing Group. All rights reserved. For permission to reuse any of this content visit http://group.bmj.com/group/rights-licensing/permissions.

BMJ Case Report Fellows may re-use this article for personal use and teaching without any further permission.

Become a Fellow of BMJ Case Reports today and you can:

- Submit as many cases as you like

- Enjoy fast sympathetic peer review and rapid publication of accepted articles

- Access all the published articles

- Re-use any of the published material for personal use and teaching without further permission

For information on Institutional Fellowships contact consortiasales@bmjgroup.com

Visit casereports.bmj.com for more articles like this and to become a Fellow 